TITLE:

\title{
MARINE INSECTS OF THE TOKARA ISLANDS -II. MARINE MIDGES (DIPTERA, CHIRONOMIDAE)-
}

AUTHOR(S):

Tokunaga, Masaaki; Komyo, Etsuko

CITATION:

Tokunaga, Masaaki ...[et al]. MARINE INSECTS OF THE TOKARA ISLANDS -II. MARINE MIDGES (DIPTERA, CHIRONOMIDAE)-. PUBLICATIONS OF THE SETO MARINE BIOLOGICAL LABORATORY 1955, 4(2-3): 363-366

ISSUE DATE:

1955-05-30

URL:

http://hdl.handle.net/2433/174514

RIGHT: 


\title{
MARINE INSECTS OF THE TOKARA ISLANDS
}

\section{MARINE MIDGES (DIPTERA, CHIRONOMIDAE) ${ }^{1}{ }^{2}$ )}

\author{
MasaAki TOKUNAGA AND ETsuko KŌMYŌ \\ Entomological Laboratory, Saikyo University
}

With 5 Text-figures

The present paper deals with marine or seashore midges collected by Messrs. S. Miyamoto, T. NAKAnE and S. UÉno, members of the survey of the Tokara Islands, from the tidal zone of a rocky seashore and coral reef at Nakanoshima. These midges are identified as follows:

Chironomidae (=Tendipedidae)

Clunioninae

1. Clunio setoensis Tokunaga (1933)

2. Telmatogeton pacificus TokUnaga (1935)

3. Thalassomyia japonica ToKunaga et Etsuko K. (n. sp.)

From Japan, hitherto, there have been known only two genera of Clunioninae, Clunio Haliday and Telmatogeton Schiner. The discovery of the genus Thalassomyia Schiner at the Tokara Islands is the first record in Japan. We intend, at present, to report this discovery with a description of a new species of the genus.

We wish to express our hearty thanks to Messrs. S. MiYamoto, T. NAKANE and S. UÉNO for their kindness in collecting these small midges which are difficult to collect.

\section{Clunio setoensis TokUnaga}

This species has been reported by Tokunaga (1933-1935) from the Pacific coast of Japan and the Ishigaki Islands. At this time, many males and nine females were collected at the rocky coral reef of the Tokara Islands.

Specimens:- Alcoholic males and females, Nakanoshima, Tokara Islands, Ryukyu, Japan; May 28 and June 12, 1953; collected by Messrs. S. MiYamoto and S. UÉNo; deposited in the Entomological Laboratory of Saikyo University.

1) Scientific Survey of the Tokara Islands, Report No. 16.

2) Contributions from the Entomological Laboratory, Saikyo University, Kyoto, No. 24.

Publ. Seto Mar. Biol. Lab., IV (2-3), 1955. (Article 30) 


\section{Telmatogeton pacificus TokunaGa}

This species has been reported by TokunaGa (1935 and 1937) from Japan and by Wirth (1947) from the Hawaiian Islands.

The midges collected at the Tokara Islands are smaller, being about $2 \mathrm{~mm}$ in body length and the development of the body setae are more slight than in the original description. The antennae of some specimens are 6-segmented. The reduction of the antennal segments of this species is not rare and has been studied in detail by ToKunaga and Yoshimura (1935).

Specimens:- Alcoholic males; Nakanoshima, Tokara Islands, Ryukyu, Japan; June 10, 1953; collected by Mr. S. UÉNO; deposited in the Entomological Laboratory of Saikyo University.

\section{Thalassomyia japonica ToKUnAGA et ETSUKo K. (sp. nov.)}

(Figs. 1-5)

Male:- Body length about 3.5-3.8 $\mathrm{mm}$; general color yellowish brown; scutellum and legs brown; abdomen brownish grey, its ventral side paler; wings smoky brown; halters white.

Antennae (Fig. 1) 7-segmented; each flagellar segment with four strong setae; distal segment with a terminal papilliform projection; ratio of segments about $27: 32: 15: 15: 13: 13: 33$. Palpi long, 4-segmented, with setae dense on second segment, sparse on other segments and quite sparse on fourth. Paraglossa ovoid and bristly, slightly smaller than second palpal segment. Clypeus covered with dense and long bristles; vertex covered with bristles.

Pronotum very narrowly separated at middle and each lateral lobe narrow, with about fourteen setae. Mesonotal setae in pattern as in Fig. 2; scutellum with about twenty-six setae; postscutellum bare.

Wings (Fig. 3) about $3 \mathrm{~mm}$ long and $0.7-1 \mathrm{~mm}$ wide, covered with microtrichia, appearing smoky brown; veins brown. Costa, $R, R_{1}$ and $R_{s}$ densely set with strong dark brown setae; other veins without setae; squama fringed with hairs and alula bare. Venation: $R_{1}$ about a quarter of $R_{s}, R_{s}$ evenly curved at distal part, cross-vein $\mathrm{r}-\mathrm{m}$ far before the middle of wing, medio-cutital fork distinctly beyond $\mathrm{r}-\mathrm{m}, \mathrm{Cu}_{1}$ strongly curved at distal part.

Legs long, densely setigerous with short setae; longest of those setae shorter than twice of diameter of segment; ratio of segments as follows:

$$
\begin{aligned}
& \text { Fore } \cdots \cdots 35.5: 41: 23: 9: 5: 2 \quad: 4 \\
& \text { Middle } \cdots 50: 48: 20.5: 7: 4.7: 2 \quad: 4 \\
& \text { Hind } \cdots . .51 \quad: 55: 31.5: 14: 9 \quad: 2.2: 4
\end{aligned}
$$

Femora thickened basally; tibiae slender; tarsal segments cylindrical, except for fourth segment, which is short and obcordate; last tarsal segment simple; empodium long 


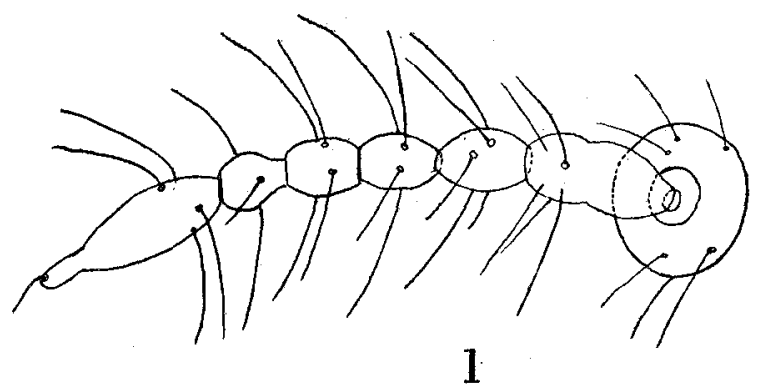

2
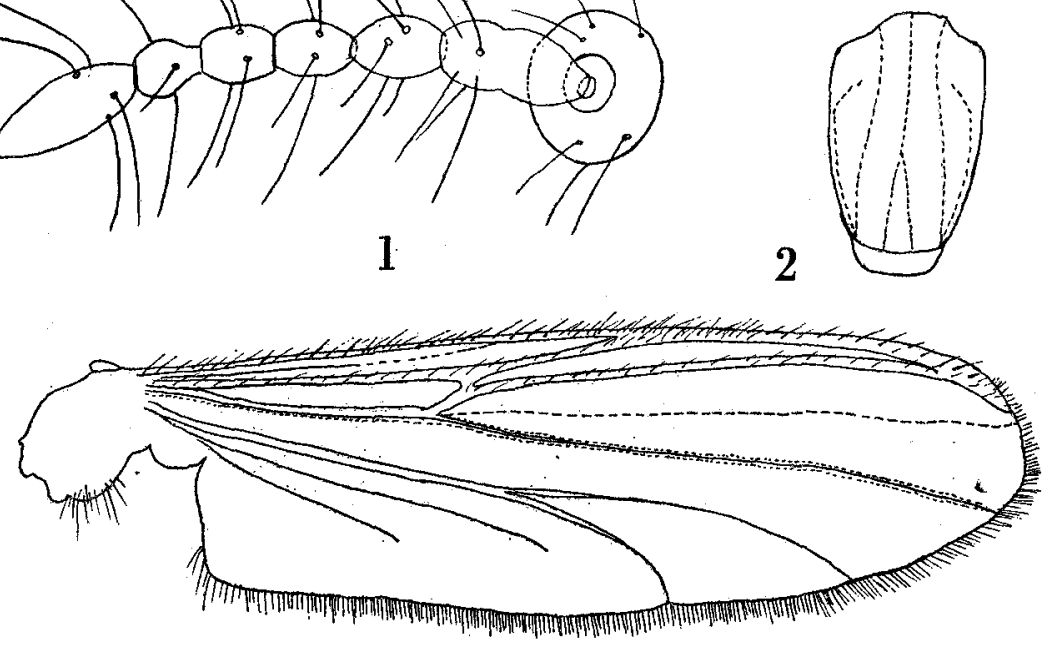

3
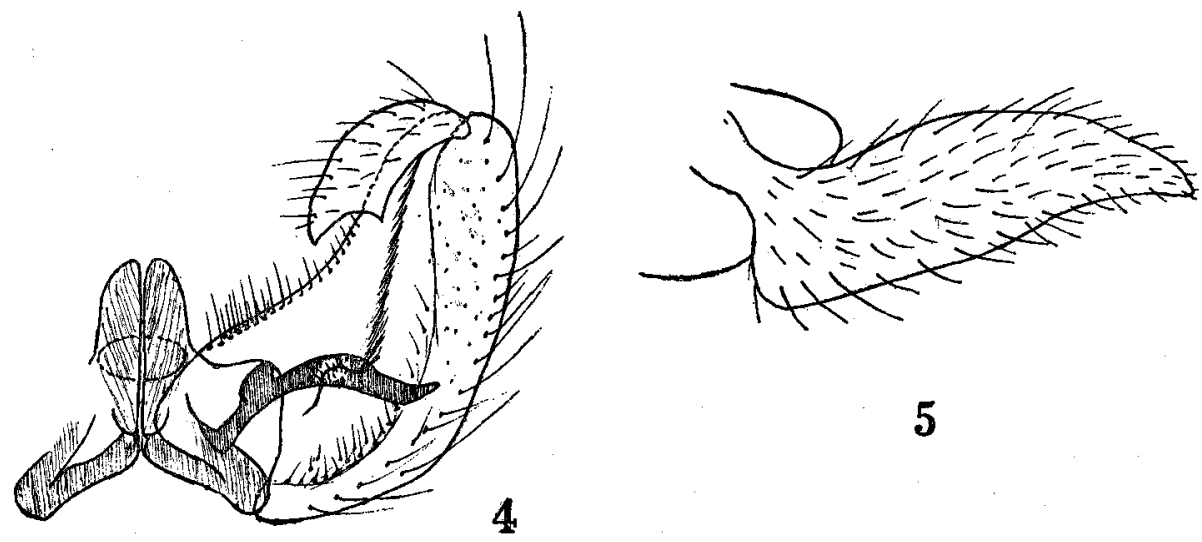

5

Thalassomyia japonica sp. nov.

Fig. 1. Male antenna.

Fig. 2. Setae arrangement of mesoscutum.

Fig. 3. Male wing.

Fig. 4. Male genitalia.

Fig. 5. Female cercus.

and thinly plumose; claws slender and simple, but anterior claw of fore and middle legs are pectinate at tip; pulvilli arise from base of each claw as hyaline, almost as long as claw. 
Abdomen moderately setigerous with delicate setae. Male genitalia (Fig. 4) inverted, somewhat similar to that of $T$. bureni WIRTH, except for the shape of the dististyle, which is specific in shape, being somewhat rhombic, extensor edge round and flexor edge angulated; basistyle with a row of very strong bristles along mesal edge of sternal side and a small blunt tubercle on basal part of tergal side.

Female:- Body length about $3.5-3.8 \mathrm{~mm}$; generally as in male, usually stouter than male. Abdomen stout, taper at caudal part. Cerci (Fig. 5) elongate, about four times long as basal width, setigerous with minute setae, slightly curved downwards at tip; subgenital plate setigerous on distal part; with U-shaped median incision on caudal margin; lateral side of genital segment without distinct setigerous patch. Claws of all legs simple. Wings about $3.8 \mathrm{~mm}$ long, $0.7 \mathrm{~mm}$ wide.

Habitat:- Tidal zone of rocky shore and coral reef, Pacific coast, Japan.

Holotype:- Male; Nakanoshima, Tokara Islands, Ryukyu, Japan; June 10, 1953.

Allotopotype:- Female; June 10, 1953.

Paratopotypes:- Many males and females; June 3 and 10, 1953.

Type specimens:- Alcoholic and dry; deposited in the Entomological Laboratory of Saikyo University; collected by Messrs. S. Miyamoto, T. Nakane and S. UÉno.

This species is very closely allied to $T$. bureni WIRTH, but distinctly specific in the following points: the arrangement of the setae on the mesonotum is rather similar to that of T. maritima WIRTH, the wings are not provided with setae on base of $M$, $\mathrm{Cu}$ and $1 \mathrm{~A}$, the longest setae of the legs are shorter than twice of diameter of the segment, the abdomen of both sexes is not laterally compressed, and the dististyle of the male genitalia is somewhat rhombic in sternal aspect.

\section{LITERATURE}

Tokunaga, M. 1933. Chironomidae from Japan (Diptera). I. Clunioninae. Philip. Jour. Sci., 51 (1) : 87-98.

1935. Chironomidae from Japan (Diptera). V. Supplementary report on the Clunioninae. Mushi, 8(1): 1-20.

1937. Marine Diptera from the Danjo Islands. Biogeographica; Trans. Biogeogr. Soc. Japan, 2(1): 34-38.

1937. Family Chironomidae (1). Fauna Nipponica 10 (Fas. VII, No. 1). Tokyo. and YoshimuRA, Y. 1936. Reduction of the antennae of a marine midge, $\mathrm{Tel}$. matogeton pacificus TokunAGA. Dobutsugaku Zassi, 48: 222-224 (in Japanese).

Wirth, W. W. 1947. Notes on the genus Thalassomyia Schiner, with descriptions of two new species (Diptera: Tendipedidae). Proc. Hawn. Ent. Soc., 13 (1): 117-139.

- 1947. A review of the genus Telmatogeton SCHINER, with descriptions of three new Hawaiian species (Diptera: Tendipedidae). Proc. Hawn. Ent. Soc., 13(1): 143-191.

1949. A revision of the Clunioninae midges with descriptions of a new genus and four new species (Diptera: Tendipedidae). Univ. California Publ. Ent., 8 (4): 151-182. 